\title{
An Assessment of Mandatory Disclosure in the Annual Reports of Serbian Listed Companies
}

\author{
Dejan Spasić ${ }^{1}$, Ksenija Denčić-Mihajlov ${ }^{2},{ }^{1,2}$ Faculty of Economics, University of Niš
}

\begin{abstract}
This paper investigates Serbian financial reporting regulation and the level of its harmonization with $\mathrm{EU}$ regulatory framework, as well as the disclosure practices of listed companies in Serbia. More precisely, we examine to what extent companies listed on the Belgrade Stock Exchange comply with the disclosure requirements of IFRS/IAS for the financial year ending in 2012. In order to assess the extent of the disclosure quality we develop the Serbian disclosure index.
\end{abstract}

Keywords - Financial reporting, disclosure index, transparency, Serbian stock exchange.

\section{INTRODUCTION}

The process of communication of enterprises with their environment involves continuous exchange of financial, as well as non-financial information. With the purpose of achieving competitive advantage, it is important that enterprises use their publicity policies for providing existent and potential investors with information that is relevant for making decisions on their capital investment [45]. Corporate publicity policy is usually based on regular annual financial reporting, as well as on other financial and non-financial disclosures. The importance of corporate disclosures is recognized in particular by companies listed on capital markets because they tend to attract new investors. Concerning corporate disclosures the listed companies are subject to special rules of capital market authorities. In addition to annual reports, they have to provide interim financial reports which should provide information related to short and regular semiannual or quarterly intervals, as well as the disclosure of the so-called ad-hoc information in cases when this extraordinary disclosure should protect the investors' interests and improve competitive advantage [45].

Protection of investors' interests by providing them with relevant and reliable information is one of the goals of harmonization process within European Union. Since the middle of last century the European Commission and its bodies have been engaged in an intensive work on passing directives, regulations and other documents in order to harmonize company disclosures. Transparent reporting of companies listed on capital markets involves mandatory disclosure of a classic set of financial reports as well as voluntary reports to the public and investors. Within that process, what matters is not only the quantity of reports, but also the quality of the disclosed financial information [45].

Even though the structure and the content of corporate annual reports for companies operating in Serbia are determined by a set of common minimum requirements of the Law on Accounting, the Law on the Capital Market, accounting standards and the regulations of the Securities Commission and the Belgrade Stock Exchange, there are still substantial differences in the disclosure level among Serbian companies and across the time.

This paper investigates the disclosure practices of listed companies in Serbia in order to examine how they comply with mandatory rules established by Serbian regulatory bodies. More precisely, we examine to what extent the companies listed on the Belgrade Stock Exchange comply with the disclosure requirements of IFRS/IAS for the financial year ending in 2012. In order to assess the extent of the disclosure quality we develop the Serbian disclosure index. This paper contributes to the growing number of literature on the quality of corporate mandatory disclosure and the findings of the study would be of great interest to listed companies, foreign investors, as well as regulatory bodies.

The remainder of this paper is organized as follows: Section 2 gives an overview of the Serbian financial reporting regulation and level of its harmonization with the EU regulatory framework in this area. In Section 3 the Serbian disclosure index is developed and the empirical results are discussed. The final section summarizes the main conclusions and implications of the paper.

\section{REGULATORY FRAMEWORK OF REPORTING OF LISTED COMPANIES IN THE EU AND ON THE SERBIAN CAPITAL MARKET - COMPARATIVE ANALYSIS}

\section{A. Harmonization Process in the EU}

The start of harmonization of trading rules on organized capital markets in the EU and the associated requirements for financial reporting date back to the early seventies of the twentieth century. In the first three decades, the progress in that field was slow and modest. In May 1999, the European Commission adopted "Financial Services Action Plan" [9] overall objective of which was to provide conditions for optimal development of single financial market. This overall objective defined three specific strategic objectives covering range of measures and deadlines for their realization. These objectives concerned the process of financial reporting of the participants on the capital markets in the EU, as well as the requirements related to reliability and transparency of information.

As a result of the process of harmonization of financial reporting, the following directions and regulations were adopted (listed in chronological order):

- The so-called "Fair Value - Directive" [13] of 2001, which enabled valuation of financial instruments at fair value (in accordance with IAS 32 and IAS 39) in the 
course of financial reporting in the form of individual and consolidated accounts of companies and banks - in accordance with the Fourth and Seventh Directives of the EEC.

- Regulation on direct application of IAS of 2002, which required all EU companies, whose securities are admitted to trading on the EU capital markets, to prepare their consolidated accounts in accordance with IAS/IFRS [39]. This Regulation stimulated other companies as well to apply the aforementioned standards in the process of reporting.

- The so-called "Directive on insider dealing and market manipulation" [15] of January 2003, which, among other things, regulated the disclosure of periodical, that is, the so-called "ad-hoc" reports - as a way of eliminating information assymetry among the participants on the capital markets.

- The so-called "Modernization Directive" [14] of June 2003, which amended the Fourth and the Seventh Directives of the EEC, as well as the Directives regulating the process of reporting of banks, other financial institutions and insurance companies. This Directive was partly amended in June 2006 [20].

- Prospectus Directive [16] of November 2003, which regulated the contents of this document when securities are admitted to trading on the capital markets in the EU.

- Directive on the transparency of requirements in relation to information about companies whose securities are admitted to trading on the regulated markets in the EU [17], whose implementation was specified in the Directive on the detailed rules for the implementation of the Directive 2004/109/EC [21].

From the standpoint of the EU companies, obligation of applying the above-mentioned acts depends on whether their securities are admitted to trading on the regulated markets within the EU, whether they are regarded as companies with the obligation of preparing consolidated financial reports and whether national legislation of a specific member state regulates the obligation of applying IAS/IFRS.

Apart from the aforementioned Directives, the European Commission passed several reccomendations related to the disclosure of additional information. These are: Commission Recommendation on the reporting on the remuneration of board members and other executive directors [18]; as well as Commission Recommendation on reporting on the role of non-executive directors or supervisory board members in listed companies [19]. These recommendations are in accordance with tendencies towards establishing harmonized codex of corporate management in European companies based on the plan adopted in 2003 [10].

With the purpose of testing the applicability of the Transparency Directive, in 2010, the European Commission submitted the Report on the implementation of this Directive [23] to the European Parliament and other relevant EU bodies. This Report was based on the external study of Mazars consulting group conducted in 2009 [32]. According to the study, "a review of issuers' practices shows that issuers generally comply with financial reporting obligations and that this is also the perception of stakeholders. Financial information disclosed is considered useful and sufficient for investment purposes" [32, Paragraph 7]. In spite of this generally positive conclusion, the Commission held that, on the basis of the results of the External study, it was necessary to make certain changes in the Transparency Directive [45]. In that regard, in October 2011, the Commission prepared the Proposal for amending the Transparency Directive [24].

\section{B. Legal Framework in Serbia}

Legal framework of financial reporting in Serbia includes the Law on Accounting [50], the Law on Auditing [51] and by-laws regulating specific issues covered by laws in more detail. With respect to listed companies, additional requirements are contained in the Law on the Capital Market [53] and by-laws issued under that law, Regulation of the Securities Commission of the Republic of Serbia, as well as the rules of the Belgrade Stock Exchange (e.g. the Rules on Listing of the Belgrade Stock Exchange [37]).

Corporate reporting in Serbia is still based on traditional disclosure of financial statements in accordance with international GAAP. Namely, companies listed on the Belgrade Stock Exchange, regardless of the size, submit financial statements in compliance with IFRS. Consequently, all disclosures required by IFRS must be realized in the financial statements of companies listed on Serbian capital market.

In addition, the underdevelopment of the capital market influences the fact that the investors make their decisions on the basis of information contained in the basic (regular, annual) financial statements. Since the information is not sufficient for making the appropriate decision on capital investments, existing and potential investors are interested in the disclosure of additional information. Their information needs created the need for not only quantitative, but also qualitative improvement of the traditional model of financial reporting [45].

In order to meet those requirements, as noted above, listed entities must also comply with the requirements of the Law on the Capital Market, by-laws passed on the basis of this law (e.g. Rulebook on the content, form and manner of publishing annual, semi-annual and quarterly reports of public companies [38]) and the Regulations of the Securities Commission of the Republic of Serbia, as well as the rules of the Belgrade Stock Exchange.

The Law on the Capital Market [53] proscribes the obligation of a public company to prepare an annual report, disclose it in public and submit it to the Serbian Securities Commission as well as to the Belgrade Stock Exchange. Apart from that, public company is obliged to create interim semiannual and quarterly reports. Annual report includes: (a) annual financial reports accompanied with the auditor's report; (b) annual business report of the company; and (c) statement of the persons responsible for the preparation of annual report. Mandatory disclosures in annual business report of the company are: 
1) fair presentation of the development and performances of a company, especially its financial position and information that is important for the assessment of the company's assets;

2) the description of the expected development of the company in the forthcoming period, changes in its business policies and main risks and threats that the company is faced with;

3) all important business events that occurred after the financial year for which the report is being prepared had ended;

4) all significant operations with related parties;

5) the company's activities in the field of research and development.

In accordance with the European Union Transparency Directive [17], Serbian Law on the Capital Market requires disclosure of additional information, for example data on significant participation, information on the acquisition of shares not later than four days from the day of acquisition, information about dividend payment and the like.

Regulations of the Securities Commission of the Republic of Serbia include rules, decisions, instructions and opinions, all in accordance with the law. One of the most important regulations of the Commission is the Rulebook on the contents and manner of public companies' reporting and notification on possession of voting shares which governs the following spheres: (1) manner and deadlines for submission of financial reports and reports on audited financial reports; (2) contents and manner of disclosing extracts from financial reports of public companies; (3) contents and manner of disclosing annual report on the operations of a joint stock company whose shares are admitted to trading on an organized market; (4) contents and manner of disclosing the statement on semiannual operations plan of the joint stock company whose shares are admitted to trading on an organized market; (5) contents and manner of disclosing the report on important events and contents of the public company's request for nondisclosure of the report on important event; (6) contents and manner of disclosing the notification on the possession of voting shares.

The analysis of regulations in the field of financial reporting of entities listed on the Serbian capital market points to a high level of compliance with the EU regulations [46].

\section{SERBIAN MANDATORY DISCLOSURE INDEX DEVELOPMENT}

\section{A. Serbian Mandatory Disclosure Index Development and Data Collection}

In order to analyze the transparency of reporting of companies listed on the Belgrade Stock Exchange, the Serbian mandatory disclosure index was developed. In the course of this process, we started from the above-mentioned Regulations of the Serbian Securities Commission, legal regulations and requirements arising from IFRS with respect to the disclosure of appropriate information that enable the analysis of financial status, profitability and cash flows and provide the basis for predicting future business trends. We identified 25 items and divided them into five sub-segments of SMDI (Table I).

The first two groups are not the direct product of financial statements. They served the purpose of ensuring confidence in the process of financial reporting of a company. Therefore, within the first group, we evaluated the disclosure of general information about the company, which was supposed to show the general business conditions - share price information (movement during the year, or at least minimum and maximum share price during the year), information about subsidiaries and/or parent companies (serving as important information about the business environment in which the company operates and its ability to influence the company's operations or the ability of the company to influence operations of related companies), number of employees (serving as non-financial measure of the company's "power"). Information about the voting shares held by the company's directors was discussed in the context of evaluating the management's potential to manipulate information disclosed in financial statements. Since the construction of complete trust in the process of preparing and disclosure of financial statements requires establishing a system of corporate governance, the fact whether the company discloses the principles and practices of corporate governance or not was taken as a separate item. Beekes, Brown and Chin [4] and Coles [8] used their study to show that firms with better corporate governance mechanism provide more informative disclosures.

TABLE I

MANDATORY DISCLOSURE INDEX DEVELOPMENT

\begin{tabular}{|l|}
\hline Disclosure index items \\
\hline I. General information about company \\
\hline 1. Share price information (SPI) \\
\hline 2. Information about subsidiaries and/or parent company (SPC) \\
\hline 3. Number of employees (NE) \\
\hline 4. Shares owned by directors (SHD) \\
\hline 5. Corporate governance codex (CGC) \\
\hline II. General financial reporting information \\
\hline 1. Statement of the responsible person (SRP) \\
\hline 2. Auditors' report disclosed (AR) \\
\hline 3. Remuneration of directors (REM) \\
\hline 4. Interim financial reports (IFR) \\
\hline III. Accounting principles and practices \\
\hline 1. Disclosure of accounting policies (DAP) \\
\hline 2. Disclosure of accounting estimates (DAE) \\
\hline 3. Disclosure of income taxes and deffered tax calculation (DIT) \\
\hline 4. Disclosure of trasactions with related parties (DTSP) \\
\hline 5. Disclosure of segment information (DSI) \\
\hline $\begin{array}{l}\text { IV. Reporting on significant events that have affected the business } \\
\text { performance }\end{array}$ \\
\hline $\begin{array}{l}\text { 1. Disclosure of changes in accounting estimates and corrections of prior } \\
\text { period errors (CH) }\end{array}$ \\
\hline 2. Disclosure of events after the reporting period (EART) \\
\hline 3. Disclosure of contingent liabilities and contingent assets (CONT) \\
\hline
\end{tabular}




\begin{tabular}{|l|}
\hline 4. Disclosure of the effect of foreign currency traslation (EFCT) \\
\hline 5. Disclosure of other revenues and other expenses (OROE) \\
\hline V. Forecast relevant information \\
\hline 1. Earnings per share (EPS) \\
\hline 2. Dividend per share (DPS) \\
\hline 3. Appropriation of retained earning (ARE) \\
\hline 4. R\&D activities (RDA) \\
\hline 5. Risks (RISK) \\
\hline 6. Expected business development in the future (DEV) \\
\hline
\end{tabular}

General information on the preparation and disclosure of financial statements (the second group of items in determining SMDI) were discussed in the context of transparency of that process. The assessment of credibility of financial statements was performed on the basis of the disclosure of two statements. First, the statement made by the responsible person (whose name and function shall be clearly indicated, to the effect that, to the best of their knowledge, the financial statements prepared in accordance with the applicable set of accounting standards give a true and fair view of the assets, liabilities, financial position and profit or loss of the issuer - in accordance with Directive 2004/109/EC [17]), and second, the existence of public disclosure of the report provided by the independent auditor was taken into account. In addition, in the context of assessing credibility of financial statements, we also took into account the (non)disclosure of information on the directors' remuneration and other compensations. Brickley et al. [5], indicate that mandatory manager compensation disclosure improves corporate governance by public monitoring and rewards to executives such that the disclosure interests are consistent with the creation of shareholders value. Besides, the transparency of directors' compensation information is to signal good governance mechanism that can reduce the cost of capital and increase firm value [42], [43]. Within this group, information on the disclosure of interim financial reports was also taken as a measure of transparency and timeliness of information provision.

Key disclosures regarding assumptions and practices of financial reporting, as the factors affecting the value of SMDI, are encompassed in the items belonging to the third and the fourth group. Clear disclosure of accounting policies and accounting estimates (for example, the useful life of fixed assets, the actuarial assumptions used in determining provisions, the classification of financial instruments and the like), helps users of financial statements in understanding the tendency of management towards using the right to choice and (non)conservatism. The tendency towards openness in reporting is complemented with the information on taxes and deferred tax calculation, given that tax legislation in Serbia contains specific requirements regarding recognition of certain types of revenues and expenses and determining taxable results. In addition, the disclosure of deferred tax allows for the forecasting of future cash flow on this basis. Since the establishment of SMDI used data only at the level of individual financial statements, special attention was paid to the analysis of the manner of disclosing information on related-party transactions (disclosure of transactions with subsidiaries and/or parent company). This was important in order to evaluate in a better way the importance of individual companies in the group and the parent company's ability to influence the operations of subsidiaries and material significance of the effects of intragroup transactions on individual financial statements. Segment information is an important item within SMDI because it increases the value relevance of accounting numbers [7], it improves monitoring over management decisions [29] and finally, the quality of segment disclosure is associated with a lower cost of equity capital and the probability of information based trading (i.e., a measure of information asymmetry among investors) [41].

Disclosures regarding significant events that have affected the business performances (the fourth group of SMDI items) are, in our opinion, essential for the assessment of management's tendencies towards disclosure of specific accounting policies. While disclosures from the previous (third) group included the most common and basic accounting policies, the fourth group included either more complex issues or more detailed disclosures. Although Buchman and Fort [6] show that, from an earnings forecast accuracy perspective, there is no advantage to calculating and presenting the cumulative effect of an accounting change, because in years subsequent to the year of change there were no significant differences in forecast errors, such disclosures in accordance with IAS 8 allow for an analysis of changes in financial position and profitability of the company in the previous period and general comparability of financial statements over time. This analysis, together with the disclosure of events after the reporting period, forms the basis for making future decisions. Contingent liabilities and contingent assets often lead to moral hazard, which could significantly increase the risk of investing particularly in the case of their nondisclosure. Disclosures of the effect of foreign currency translation has special significance in Serbia, since the state adopted a special Rulebook allowing, contrary to IAS 21, the recognition of negative exchange differences as accrued expenses - as a solution which temporarily postpones these negative effects on the result through the balance sheet. Having in mind the fact that, during the analyzed period, in a large number of companies in Serbia other income and other expenses have a significant share in the total revenue $(4.88 \%)$ and total expenditures $(5.26 \%$ ) [2] and thus in the financial results, in the process of determining elements of SMDI we also took into consideration the level of disclosure in the notes to this group of revenues and expenses.

Disclosures which may be used for the prediction of future net earnings belong to the fifth group (with six items relating to forecast relevant information). Information about earnings per share, dividends per share and appropriation of retained earnings provide historical data on past and expected earning capabilities and distribution policy that can be expected in the future. There are numerous studies that show the proper relationship of these variables, as in [3], [33], [48]. However, there are studies that indicate a different relationship as for example, in [28], [36]. Information on R \& D activities, risks 
and the expected business development are an integral part of each business report. Although the content of this report is, in principle, created voluntarily, Serbian Securities Commission requires that listed companies include the above information as part of their report, which is the reason why they are considered as mandatory disclosures. In addition, risk disclosure is also the requirement of International Financial Reporting Standards, particularly IFRS 7, which explains the reason why such information can be found in the notes. Individually speaking, all three disclosure items contribute to overcoming information asymmetry and forecasting the future development of the company. Thus, for example, Merkley [34] found in his study that "the relation between earnings performance and $\mathrm{R} \& \mathrm{D}$ disclosure is consistent with managers providing more information to help investors, rather than using disclosure to spin or obfuscate the firm's performance". Also, R \& D investments are associated with significantly high level of risk and information asymmetry with respect to their potential outcomes [1], [31]. Users of financial statements supplement the assessment of future business development with the analysis of disclosed risk, as well as with a narrative description of expected business development from management's perspective.

\section{B. Coding of the Index}

Previous studies were not based on a unique coding of items for calculating the disclosure index. The reason for this approach lies in the fact that it is impossible to determine the same weighting factor for all items, primarily because of the complexity of disclosure. Generally speaking, SMDI items (Table I) in this study were coded with 0 (if the information was not disclosed) or 1 (if the information was disclosed).

However, in specific cases we used weights 0,1 and 2. This was the case for 7 items. At the same time, some items (Disclosure of accounting estimates, Disclosure of transactions with subsidiaries and/or parent company, Disclosure of income taxes and deferred tax calculation and Disclosure of contingent liabilities and contingent assets) were assigned weight 0 if there was no disclosure, 1 - if basic information was disclosed with no quantitative or narrative explanations and $2-$ if the disclosure was complete, i.e., if it contained all the necessary explanations. On the other hand, for the item Corporate Governance Codex weight 0 was assigned if the information whether the codex was applied was not disclosed, 1 - if the codex of some other organization (e.g., OECD or the Serbian Chamber of Commerce) was applied and $2-$ if its own codex was applied. With respect to information on the directors' remuneration, weight 1 was assigned if the sum of remuneration of all directors was disclosed, and weight $2-$ if remunerations were shown separately for each director. Only narrative risk disclosures were coded with 1 , while narratively described and quantified risks were coded with 2 .

There is a possibility that some companies did not disclose some information either because they did not want to or because the information did not exist (for example, information on related companies, and information on shares held by the director). Even when some item did not exist, we considered that the company should have disclosed such information (e.g., "There are no related companies and transactions with them", or "directors do not possess shares"), which is why, regardless of the reason for the absence of some information, such non-disclosure was assigned weight 0 .

\section{EMPIRICAL ANALYSIS}

\section{A. Sample Determining and Data Collection}

The sample includes 63 companies from the Belgrade Stock Exchange (5 from the Prime market, 2 from the Standard market and 56 from the Open Market). Banks and other financial organizations (e.g., insurance companies) were excluded from the sample, given that they are subject to special rules of the National Bank of Serbia regarding financial reporting and have a different form and content of financial statements. The sample includes only non-financial companies whose common shares with voting rights are listed on a specific market segment.

Prime market does not include financial institutions as issuers, which means that all companies belonging to this market segment were included in the sample.

Standard market includes shares of 3 issuers, one of which is a bank, so that the sample included two non-financial companies.

The open market involves the total of 99 issuers, one of which issues preference shares only, whereas 98 issuers issue ordinary shares with voting rights (5 issuers listed preference shares in addition to ordinary shares). The initial sample of 98 issuers was first reduced by 11 (banks and other financial organizations), and then by 3 additional issuers that are in the process of restructuring within the privatization process. Namely, according to the Law on Privatization [49], stateowned enterprises with poor performance before privatization undergo restructuring under the supervision by the state. In addition, 4 companies with losses in excess of capital were also excluded from the initial sample since they were regarded as companies that were likely to be introduced in the process of bankruptcy. The remaining sample of 80 companies (98-113-4) was further analyzed in accordance with the multiple criteria. We decided to exclude another 24 companies with market capitalization less than 100 million RSD (equivalent less than 1 million EUR). With respect to these companies, we observed an extremely small number of transactions on the capital market. In addition, the reason for non-inclusion of these companies in the sample lay in the fact that their total joint market capitalization equaled $0.61 \%$ of the total market capitalization of all issuers on the Open market. Thus, the sample from the Open Market numbered 56 companies.

For calculating SMDI we used financial statements, business report and other reports prepared and published exclusively by the company. These reports are available on the website of the Belgrade Stock Exchange and on companies' own websites (if they have any). We did not take into consideration the information published by the Belgrade Stock Exchange for each issuer (for example, on the website of the Belgrade Stock Exchange it is possible to find information on 
the movement of share prices, EPS and the like), but only disclosures found in the reports prepared and published by companies themselves. Certain disclosures were treated as mandatory in accordance with the Law on the Capital Market and the Regulations of the Serbian Securities Commission. These were the disclosures related to the movement of share prices (minimum and maximum price), directors' earnings, shares held by directors, the distribution of income and the amount and date of dividend payment, significant transactions with related parties, R \& D activities, risks and expected business development, application of corporate governance codex. Information on the other SMDI items was taken from annual and interim financial statements of companies.

The compliance level is the percentage to which each of the analyzed firms complies with the mandatory disclosure requirements in Serbia. It is calculated as a ratio of company's mandatory index score and maximal value of the mandatory disclosure score (33).

\section{B. Empirical Results}

The mean of disclosure index is 20.17 , which leads to the average level of disclosure compliance with national regulation and IAS/IFRSs requirements in the sample of $64.34 \%$ (Table II). The values of minimum $(18.18 \%)$ and maximum $(93.94 \%)$ level of compliance indicate significant variations in the level of disclosure compliance with IAS/IFRSs in Serbia. In comparison with the level of disclosure compliance in the developed countries (e.g., $81 \%$ in Germany [27], $74 \%$ in Switzerland [47], $86 \%$ in Greece [26]), the accounting disclosure in Serbia is still at a low level. This suggests the need for the improvement in the level of information disclosure of the sample companies.

TABLE II

List of ENTITIES In THE SAMPLE - By Size, SEgment of CAPITAL MARKET, SECTOR OF INDUSTRY AND THEIR WeIGHTED DisClOSURES BY SEGMENTS AND TOTAL

\begin{tabular}{|c|c|c|c|c|c|c|c|c|c|c|}
\hline & \multirow{3}{*}{ Full name of issuer of common shares } & \multirow{3}{*}{$\begin{array}{l}\text { Market } \\
\text { segment }\end{array}$} & \multirow{3}{*}{ Sector** } & \multicolumn{6}{|c|}{ Sum of weighted disclosures } & \multirow{3}{*}{$\begin{array}{l}\text { Compliance } \\
\text { level } \\
(\text { in } \%)^{*}\end{array}$} \\
\hline & & & & \multicolumn{5}{|c|}{ Segment of SMDI } & \multirow{2}{*}{$\begin{array}{l}\text { TOTAL } \\
\text { SMDI }\end{array}$} & \\
\hline & & & & $I$ & II & III & IV & V & & \\
\hline 1. & Aerodrom Nikola Tesla a.d., Beograd & Prime & $\mathrm{H}$ & 2 & 5 & 6 & 5 & 5 & 23 & $69.70 \%$ \\
\hline 2. & NIS a.d., Novi Sad & Prime & B & 5 & 5 & 8 & 5 & 7 & 30 & $90.91 \%$ \\
\hline 3. & Soja protein a.d., Bečej & Prime & $\mathrm{C}$ & 4 & 5 & 8 & 2 & 6 & 25 & $75.76 \%$ \\
\hline 4. & Tigar a.d., Pirot & Prime & $\mathrm{C}$ & 6 & 5 & 8 & 5 & 7 & 31 & $93.94 \%$ \\
\hline 5. & Alfa plam a.d., Vranje & Standard & $\mathrm{C}$ & 3 & 5 & 3 & 2 & 3 & 16 & $48.48 \%$ \\
\hline 6. & Metalac a.d., Gornji Milanovac & Standard & $\mathrm{C}$ & 4 & 5 & 7 & 1 & 6 & 23 & $69.70 \%$ \\
\hline 7. & Autoprevoz a.d., Čačak & Open & $\mathrm{H}$ & 3 & 4 & 7 & 3 & 5 & 22 & $66.67 \%$ \\
\hline 8. & Bambi Banat a.d., Beograd & Open & $\mathrm{C}$ & 2 & 3 & 8 & 4 & 6 & 23 & $69.70 \%$ \\
\hline 9. & Crvenka fabrika šećera a.d., Crvenka & Open & $\mathrm{C}$ & 3 & 3 & 8 & 4 & 6 & 24 & $72.73 \%$ \\
\hline 10. & Dijamant a.d., Zrenjanin & Open & $\mathrm{C}$ & 4 & 5 & 8 & 4 & 6 & 27 & $81.82 \%$ \\
\hline 11. & Energomontaža a.d., Beograd & Open & $\mathrm{F}$ & 2 & 4 & 7 & 5 & 2 & 20 & $60.61 \%$ \\
\hline 12. & Energoprojekt Niskogr. a.d., Beograd & Open & $\mathrm{F}$ & 4 & 4 & 8 & 4 & 6 & 26 & $78.79 \%$ \\
\hline 13. & Energoprojekt Visokogr. a.d., Beograd & Open & $\mathrm{F}$ & 4 & 4 & 8 & 4 & 6 & 26 & $78.79 \%$ \\
\hline 14. & Frikom a.d., Beograd & Open & $\mathrm{C}$ & 4 & 4 & 7 & 4 & 5 & 24 & $72.73 \%$ \\
\hline 15. & Galenika Fitofarmacija a.d., Zemun & Open & $\mathrm{C}$ & 3 & 4 & 5 & 2 & 6 & 20 & $60.61 \%$ \\
\hline 16. & Goša FOM a.d., Smed. Palanka & Open & $\mathrm{C}$ & 2 & 4 & 3 & 2 & 4 & 15 & $45.45 \%$ \\
\hline 17. & Goša montaža a.d., Velika Plana & Open & $\mathrm{C}$ & 2 & 4 & 6 & 1 & 5 & 18 & $54.55 \%$ \\
\hline 18. & Imlek a.d., Beograd & Open & $\mathrm{C}$ & 4 & 3 & 7 & 3 & 5 & 22 & $66.67 \%$ \\
\hline 19. & Impol Seval a.d., Sevojno & Open & $\mathrm{C}$ & 4 & 3 & 5 & 3 & 5 & 20 & $60.61 \%$ \\
\hline 20. & Informatika a.d., Beograd & Open & $\mathrm{C}$ & 3 & 4 & 6 & 2 & 5 & 20 & $60.61 \%$ \\
\hline 21. & Jedinstvo Sevojno a.d., Sevojno & Open & $\mathrm{F}$ & 4 & 4 & 4 & 1 & 4 & 17 & $51.52 \%$ \\
\hline 22. & Jugohemija a.d., Beograd & Open & $\mathrm{G}$ & 2 & 3 & 7 & 4 & 4 & 20 & $60.61 \%$ \\
\hline 23. & Kopaonik a.d., Beograd & Open & $\mathrm{C}$ & 2 & 4 & 5 & 2 & 4 & 17 & $51.52 \%$ \\
\hline 24. & Lasta a.d., Beograd & Open & $\mathrm{H}$ & 3 & 4 & 4 & 4 & 3 & 18 & $54.55 \%$ \\
\hline 25. & Messer Tehnogas a.d., Beograd & Open & $\mathrm{C}$ & 4 & 3 & 5 & 4 & 5 & 21 & $63.64 \%$ \\
\hline 26. & Mlekara a.d., Subotica & Open & $\mathrm{C}$ & 3 & 4 & 7 & 4 & 5 & 23 & $69.70 \%$ \\
\hline 27. & Montinvest a.d., Beograd & Open & $\mathrm{F}$ & 5 & 5 & 7 & 1 & 5 & 23 & $69.70 \%$ \\
\hline 28. & Neoplanta a.d., Novi Sad & Open & $\mathrm{C}$ & 3 & 5 & 6 & 3 & 4 & 21 & $63.64 \%$ \\
\hline 29. & Niška mlekara a.d., Niš & Open & $\mathrm{C}$ & 3 & 4 & 7 & 3 & 5 & 22 & $66.67 \%$ \\
\hline
\end{tabular}




\begin{tabular}{|r|l|l|l|l|l|l|l|l|l|l|}
\hline 30. & Planum GP a.d., Beograd & Open & F & 4 & 5 & 2 & 1 & 4 & $\mathbf{1 6}$ & $48.48 \%$ \\
\hline 31. & Radijator a.d., Zrenjanin & Open & C & 2 & 4 & 6 & 4 & 7 & $\mathbf{2 3}$ & $69.70 \%$ \\
\hline 32. & Ravnica a.d., Bajmok & Open & A & 1 & 3 & 2 & 0 & 0 & $\mathbf{6}$ & $18.18 \%$ \\
\hline 33. & Simpo a.d., Vranje & Open & C & 2 & 4 & 6 & 2 & 2 & $\mathbf{1 6}$ & $48.48 \%$ \\
\hline 34. & Šajkaška fabrika šećera a.d., Žabalj & Open & C & 3 & 4 & 7 & 2 & 5 & $\mathbf{2 1}$ & $63.64 \%$ \\
\hline 35. & TE - TO a.d., Senta & Open & C & 3 & 3 & 8 & 5 & 5 & $\mathbf{2 4}$ & $72.73 \%$ \\
\hline 36. & Valjaonica bakra Sevojno a.d., Sevojn & Open & C & 6 & 4 & 7 & 4 & 7 & $\mathbf{2 8}$ & $84.85 \%$ \\
\hline 37. & Veterinarski zavod Sub. a.d., Subotica & Open & C & 2 & 4 & 8 & 3 & 5 & $\mathbf{2 2}$ & $66.67 \%$ \\
\hline 38. & Vital a.d., Vrbas & Open & C & 4 & 2 & 7 & 4 & 5 & $\mathbf{2 2}$ & $66.67 \%$ \\
\hline 39. & Voda Vrnjci a.d., Vrnjačka Banja & Open & C & 4 & 4 & 7 & 4 & 5 & $\mathbf{2 4}$ & $72.73 \%$ \\
\hline & Average for the large entities & & & & & & & & $\mathbf{2 5 . 4 2}$ & $\mathbf{6 5 . 1 9 \%}$ \\
\hline
\end{tabular}

\section{A2 Medium-sized entities}

\begin{tabular}{|c|c|c|c|c|c|c|c|c|c|c|}
\hline & \multirow{3}{*}{ Full name of issuer of common shares } & \multirow{3}{*}{$\begin{array}{l}\text { Market } \\
\text { segment }\end{array}$} & \multirow{3}{*}{ Sector** } & \multicolumn{6}{|c|}{ Sum of weighted disclosures } & \multirow{3}{*}{$\begin{array}{l}\text { Compliance } \\
\text { level } \\
(\text { in } \%)^{*}\end{array}$} \\
\hline & & & & \multicolumn{5}{|c|}{ Segment of SMDI } & \multirow{2}{*}{ TOTAL } & \\
\hline & & & & $I$ & II & III & IV & V & & \\
\hline 1. & Energoprojekt holding a.d., Beograd & Prime & $\mathrm{F}$ & 5 & 5 & 7 & 5 & 7 & 29 & $87.88 \%$ \\
\hline 2. & Agrobačka a.d., Bačka Topola & Open & $\mathrm{A}$ & 2 & 4 & 3 & 1 & 4 & 14 & $42.42 \%$ \\
\hline 3. & Čoka duvanska industrija a.d., Čoka & Open & $\mathrm{C}$ & 1 & 4 & 5 & 5 & 4 & 19 & $57.58 \%$ \\
\hline 4. & Energoprojekt Entel a.d., Beograd & Open & $\mathrm{M}$ & 5 & 4 & 7 & 2 & 6 & 24 & $72.73 \%$ \\
\hline 5. & Energoprojekt industrija a.d., Beograd & Open & $\mathrm{M}$ & 4 & 4 & 7 & 5 & 4 & 24 & $72.73 \%$ \\
\hline 6. & FPM Agromehanika a.d., Boljevac & Open & $\mathrm{C}$ & 4 & 3 & 5 & 6 & 6 & 24 & $72.73 \%$ \\
\hline 7. & Luka Dunav a.d., Pančevo & Open & $\mathrm{H}$ & 4 & 3 & 7 & 3 & 2 & 19 & $57.58 \%$ \\
\hline 8. & Niva a.d., Novi Sad & Open & $\mathrm{C}$ & 2 & 4 & 5 & 4 & 4 & 19 & $57.58 \%$ \\
\hline 9. & Pionir PP Srbobran a.d., Srbobran & Open & A & 3 & 3 & 3 & 1 & 4 & 14 & $42.42 \%$ \\
\hline 10. & Planinka a.d., Kuršumlija & Open & $\mathrm{C}$ & 3 & 5 & 7 & 4 & 7 & 26 & $78.79 \%$ \\
\hline 11. & STUP Vršac a.d., Vršac & Open & $\mathrm{H}$ & 1 & 4 & 4 & 1 & 2 & 12 & $36.36 \%$ \\
\hline 12. & Sunce a.d., Sombor & Open & $\mathrm{C}$ & 3 & 3 & 6 & 4 & 5 & 21 & $63.64 \%$ \\
\hline \multirow[t]{2}{*}{13.} & Telefonija a.d., Beograd & Open & $\mathrm{F}$ & 2 & 4 & 6 & 5 & 2 & 19 & $57.58 \%$ \\
\hline & Average for medium-sized entities & & & & & & & & 20.31 & $61.54 \%$ \\
\hline
\end{tabular}

\section{A3 Small entities}

\begin{tabular}{|c|c|c|c|c|c|c|c|c|c|c|}
\hline & \multirow{3}{*}{ Full name of issuer of common shares } & \multirow{3}{*}{$\begin{array}{l}\text { Market } \\
\text { segment }\end{array}$} & \multirow{3}{*}{ Sector** } & \multicolumn{6}{|c|}{ Sum of weighted disclosures } & \multirow{3}{*}{$\begin{array}{l}\text { Compliance } \\
\text { level } \\
(\text { in } \%)^{*}\end{array}$} \\
\hline & & & & \multicolumn{5}{|c|}{ Segment of SMDI } & \multirow{2}{*}{ TOTAL } & \\
\hline & & & & $I$ & II & III & $I V$ & V & & \\
\hline 1 & Agrovršac a.d., Vršac & Open & $\mathrm{A}$ & 3 & 4 & 5 & 4 & 3 & 19 & $57.58 \%$ \\
\hline 2 & Astoria a.d., Beograd & Open & I & 2 & 3 & 4 & 1 & 2 & 12 & $36.36 \%$ \\
\hline 3 & Elektrotehna a.d., Niš & Open & $\mathrm{G}$ & 2 & 3 & 2 & 3 & 3 & 13 & $39.39 \%$ \\
\hline 4 & Excelsior a.d., Beograd & Open & $\mathrm{I}$ & 3 & 3 & 6 & 1 & 6 & 19 & $57.58 \%$ \\
\hline 5 & Gradina a.d., Užice & Open & $\mathrm{L}$ & 2 & 4 & 5 & 2 & 2 & 15 & $45.45 \%$ \\
\hline 6 & Industrijske nekretnine a.d., Beograd & Open & $\mathrm{L}$ & 3 & 3 & 4 & 2 & 3 & 15 & $45.45 \%$ \\
\hline 7 & Morava a.d., Jagodina & Open & G & 3 & 4 & 3 & 1 & 1 & 12 & $36.36 \%$ \\
\hline 8 & Nama a.d., Šabac & Open & $\mathrm{L}$ & 2 & 4 & 5 & 2 & 3 & 16 & $48.48 \%$ \\
\hline 9 & Stoteks a.d., Novi Sad & Open & $\mathrm{G}$ & 3 & 3 & 6 & 1 & 1 & 14 & $42.42 \%$ \\
\hline 10 & TP Zvezda a.d., Beograd & Open & $\mathrm{L}$ & 2 & 4 & 4 & 3 & 2 & 15 & $45.45 \%$ \\
\hline \multirow[t]{2}{*}{11} & Trgovina 22 a.d., Kragujevac & Open & $\mathrm{G}$ & 4 & 4 & 4 & 2 & 4 & 18 & $54.55 \%$ \\
\hline & Average for small entities & & & & & & & & 15.27 & $46.28 \%$ \\
\hline
\end{tabular}

${ }^{*}$ Calculated as: Total weighted disclosures by company/33(maximum of weighted disclosures) $x 100$

**Description of sectors' abbreviations:

A - Agriculture, forestry and fishing; B - Mining; C - Manufacturing; F - Construction; G -Wholesale and retail trade; $\mathrm{H}$ - Transportation and storage;

I - Accommodation and food service activities; L - Real estate activities; M - Professional, scientific and technical activities. 
The degree of disclosure is higher in companies listed on the Prime Listing in comparison to companies quoted on two other segments of regulated market (Standard Listing and Open Market). The average value of the disclosure index for companies listed on the Prime Listing is 27.60 which indicates the average level of compliance of $83.64 \%$. It is expected that companies listed on the Standard listings should be also characterized by a high disclosure quality. However, in the case of Serbian capital market, this level is lower (the average level of disclosure index is 19.50, which corresponds to compliance level of $59.1 \%$ ) because: a) there are only two non-financial companies listed on this market segment; and b) in addition, one of these companies (Alfa plam) has a low disclosure index (16) due to inadequate financial reporting and the lack of reliable financial statements, which is also confirmed by the qualified opinion in the report of the independent auditor.

Our findings indicate that the level of disclosure compliance with the requirements of national regulations and IFRS is associated with company size which is consistent with findings both in developed and developing economies, as seen in [35], [12], [26], [30]. There are several possible explanations of such a relationship between these variables. In the first place, larger companies in Serbia are more visible and economically important. They are in the center of investor attention, and, when it is needed, a focus of government intervention. Due to their size, they are able to comply more with IFRS/IAS by disclosing more comprehensive information. In such a way, they satisfy investor demands for information and build up corporate image and visibility.

\section{CONCLUSION}

The regulatory framework and accounting practices in the Republic of Serbia have undergone considerable changes, especially in the implementation and enforcement of International Financial Reporting Standards. As a country that affirms ambitions to EU accession, Serbia has had to amend its legislation to comply with the EU Directives and require listed companies to prepare their financial statements according to IFRSs. However, the harmonization with the EU accounting directives and adoption of IFRS is not fully completed. There are problems in the implementation and enforcement of new legislation and difficulties in following these regulations in practice [11].

The aim of this research on the quantity and quality of financial reporting among the Serbian listed companies is to present the picture of the current state of affairs on the domestic capital market and to provide guidance on further development and improvement of financial reporting transparency. The analyses of regulatory bases and financial reporting practices have pointed out several important issues.

1) Mandatory financial reporting is not expected to be sufficient, which is applicable to Serbia as well which is characterized by unstable market economy with poor efficiency of capital market. Foreign investors, whose share in the total volume and the number of transactions on the Serbian capital market in the period of global financial crisis is declining, prefer financial reporting above the proscribed legal minimum.

2) Mandatory disclosure practices of Serbian companies appear to be limited. The study reveals that the analyzed Serbian firms, on average, report $64.34 \%$ of the mandatory information. In this regard, significant improvements in mandatory disclosure level should be made, particularly having in mind that some companies do not provide even basic mandatory information required (minimum disclosure score is $18.18 \%$ ).

3) Low level of disclosure quality of Serbian companies could be attributed to ineffectiveness in the functions of internal and external auditors and poor corporate governance. Although a set of enforcement mechanisms to promote compliance is in place, activities of enforcement bodies have been insufficient to ensure compliance.

4) Finally, low level of disclosure quality could also be attributed to a relatively small number of companies that are subjects of strict and direct supervision of the regulatory bodies (such is the Serbian Securities Commission), i.e., that are listed on the Prime and the Standard Listing.

\section{REFERENCES}

[1] Aboody, D. and Lev, B., "Information Asymmetry, R\&D, and Insider Gains," in The Journal of Finance vol. 55, no. 6, 2000, pp. 2747-2766. http://dx.doi.org/10.1111/0022-1082.00305

[2] APR, Saopštenje o poslovanju privrede u Republici Srbiji u 2012. godiniuporedni podaci iz finansijskih izveštaja za 2011. i 2012. godinu, Beograd, 2013

[3] Aharony, J. and Dotan, A., "Regular dividend announcements and future unexpected earnings: An empirical analysis," in Financial Review, vol. 29 , no. 1,1994 , pp. $125-151$ http://dx.doi.org/10.1111/j.1540-6288.1994.tb00816.x

[4] Beekes, W., Brown, P. R. and Chin, G., "Do better-governed firms make more informative disclosures? Cana-dian evidence", in SSRN: http://ssrn.com/abstract=881062., 2007

[5] Brickley, J. A., Lease, R. C. and Smith Jr., C. W., "Corporate Voting: Evidence from Charter Amendment Proposal," in Journal of Corporate Finance, vol. 1, 1994, pp. 5-31. http://dx.doi.org/10.1016/09291199(94)90008-6

[6] Buchman, A. T. and Fort, C. P., "Alternative disclosure methods for accounting changes and analysts' earnings forecasts," in Journal of Applied Business Research, vol. 12, Issue 3, 1996, pp. 48-59.

[7] Chen, P. and Zhang, G., "Heterogeneous investment opportunities in multiple-segment firms and the incremental value relevance of segment accounting data," in The Accounting Review, no. 78, 2003, pp. 397-428.

[8] Coles, J. L., "Disclosure policy: A Discussion of Leuz, Triantis and Wang (2008) on "Going Dark"," in Journal of Accounting and Economics, vol. 45, no. 2-3, 2008, pp. 1-12.

[9] Commission of the European Communities, Financial Services Action Plan, COM(1999)232, Brussels, 1999.

[10] Commission of the European Communities, Modernising company law and Enhancing Corporate Governance in the European Union - A Plan to Move Forward, $\operatorname{COM}(2003) 284,2003$, Brussels

[11] Denčić-Mihajlov, K., Spasic, D., "Scope of corporate governance and financial reporting reform in Serbia," in Accounting and Management Information Systems No. 18/2006, Academy of Economic Studies, Faculty of Accounting and Management Information Systems, Bucharest, 2006, pp. 6-20.

[12] Depoers, F., "A cost-benefit study of voluntary disclosure: some empirical evidence from French listed companies," in European Accounting Review, vol. 9, no. 2, 2000, pp. 245-263. http://dx.doi.org/10.1080/09638180050129891

[13] European Commission, "Directive 2001/65/EC of the European Parliament and of the Council of 27 September 2001 amending Directives 78/660/EEC, 83/349/EEC and 86/635/EEC as regards the valuation rules for the annual and consolidated accounts of certain types 
of companies as well as of banks and other financial institutions," Official Journal of the European Communities, L 283, Brussels, 2001.

[14] European Commission, "Directive 2003/51/EC of the European Parliament and of the Council of 18 June 2003 amending Directives 78/660/EEC, 83/349/EEC, 86/635/EEC and 91/674/EEC on the annual and consolidated accounts of certain types of companies, banks and other financial institutions and insurance undertakings," Official Journal of the European Communities, L 178, Brussels, 2003.

[15] European Commission, "Directive 2003/6/EC of the European Parliament and of the Council of 28 January 2003 on insider dealing and market manipulation (market abuse)," Official Journal of the European Communities, L 96, 12.4.2003, Brussels, 2003.

[16] European Commission (2003), Directive 2003/71/EC of the European Parliament and of the Council of 4 November 2003 on the prospectus to be published when securities are offered to the public or admitted to trading and amending Directive 2001/34/EC, Official Journal of the European Communities, L 345, Brussels, 2003

[17] European Commission, "Directive 2004/109/EC of the European Parliament and of the Council of 15 December 2004 on the harmonization of transparency requirements in relation to information about issuers whose securities are admitted to trading on a regulated market and amending Directive 2001/34/EC," Official Journal of the European Communities, L 390, Brussels, 2004.

[18] European Commission, "Commission Recommendation 2004/913/EC of 14 December 2004 fostering an appropriate regime for the remuneration of directors of listed companies," Official Journal of the European Communities, L 385, Brussels, 2004.

[19] European Commission, "Commission Recommendation 2005/162/EC of 15 February 2005 on the role of non-executive or supervisory directors of listed companies and on the committees of the (supervisory) board," Official Journal of the European Communities, L 52, Brussels, 2005.

[20] European Commission, "Directive 2006/46/EC of the European Parliament and of the Council of 14 June 2006 amending Council Directives 78/660/EEC on the annual accounts of certain types of companies, 83/349/EEC on consolidated accounts, 86/635/EEC on the annual accounts and consolidated accounts of banks and other financial institutions and 91/674/EEC on the annual accounts and consolidated accounts of insurance undertakings," Official Journal of the European Communities, L224, Brussels, 2006.

[21] European Commission, "Commission Directive 2007/14/EC of 8 March 2007 laying down detailed rules for the implementation of certain provisions of Directive 2004/109/EC on the harmonization of transparency requirements in relation to information about issuers whose securities are admitted to trading on a regulated market," Official Journal of the European Communities, L 69, Brussels, 2007.

[22] European Commission, Simplifying the business environment for companies, Brussels, 2009.

[23] European Commission, Operation of the Directive 2004/109/EC on the harmonization of the transparency requirements in relation to information about users whose securities are admitted to trading on a regulated market $\operatorname{COM}(2010) 243$, Brussels, 2010.

[24] European Commission, Proposal for a Directive of the European Parliament and of the Council amending Directive 2004/109/EC on the harmonization of the transparency requirements in relation to information about users whose securities are admitted to trading on a regulated market and Commission Directive 2007/14/EC, COM(2011)683, Brussels, 2011.

[25] European Commission, "Directive 2012/6/EU of the European Parliament and of the Council of 14 March 2012 amending Counci Directive 78/660/EEC on the annual accounts of certain types of companies as regards micro-entities," Official Journal of the European Communities, L 081, Brussels, 2012.

[26] Galani, D., Alexandridis, A. and Stavropoulos, A., "The Association between the Firm Characteristics and Corporate Mandatory Disclosure the Case of Greece," World Academy of Science, Engineering and Technology, 2011.

[27] Glaum, M. and Street, D., "Compliance with the Disclosure Requirements of Germany's New Market: IAS versus US GAAP”, in Journal of Interna-tional Financial Management \& Accounting, vol. 14, no. 1, 2003, pp. 65-100. http://dx.doi.org/10.1111/1467-646X.00090

[28] Grullon, G., Michaely, R., Benartzi, S. and Thaler, R. H., "Dividend changes do not signal changes in future profitability," in Journal of Business, 78(5), 2005, pp. 1659-1682. http://dx.doi.org/10.1086/431438
[29] Hope, O. K. and Thomas, W. B., "Managerial Empire Building and Firm Disclosure," in Journal of Accounting Research 46, 2008, pp. 591-626. http://dx.doi.org/10.1111/j.1475-679X.2008.00289.x

[30] Juhmani, O., "Factors influencing the extent of corporate compliance with IFRS: evidence from companies listed in Bahrain Stock Exchange," in Journal of International Business and Economics, vol. 12, no. 2, 2012, pp. 67-84.

[31] Kothari, S. P., Laguerre, T. E. and Leone, A. J., "Capitalization versus Expensing: Evidence on the Uncertainty of Future Earnings from Capital Expenditures versus R\&D Outlays," in Review of Accounting Studies vol. 7, no. 4, 2002, pp. 355-382. http://dx.doi.org/10.1023/A:1020764227390

[32] Demarigni, F. and Clerc, C., "Study on the application of selected obligations of directive 2004/109/EC on the harmonization of transparency requirements in relation to information about issuers whose securities are admitted to trading on a regulated market, " Mazars, 2009

[33] McCluskey, T., Burton, B. M., Power, D. M. and Sinclair, C. D., "Evidence on the Irish stock market's reaction to dividend announcements," in Applied Financial Economics, vol. 16, no. 8, 2006, pp. 617-628. http://dx.doi.org/10.1080/09603100600639058

[34] Merkley, J. K., "Narrative Disclosure and Earnings Performance: Evidence from R\&D Disclosures" (Feb. 1, 2013), Johnson School Research Paper Series No.4-2012., [Online] Available: http://ssrn.com/abstract=1974916, [Accessed: July 5, 2013]

[35] Michailesco, C., "The determinants of the quality of accounting information disclosed by French listed companies," presented at EAA Congress, Bordeaux, 1999.

[36] Nissim, D. and Ziv, A., "Dividend changes and future profitability," in Journal of Finance, vol. 56, no. 6, 2001, pp. 2111-2133. http://dx.doi.org/10.1111/0022-1082.00400

[37] „Pravilnik o listingu Beogradske berze A.D. Beograd,“ Dokument br. 04/2 br. 3163-1/12, Beograd, 2012.

[38] "Pravilnik o sadržini, formi i načinu objavljivanja godišnjih, polugodišnjih i kvartalnih izveštaja javnih društava," Sl. glasnik $R S$, br. 14/2012, Beograd, 2012.

[39] "Regulation (EC) No 1606/2002 of the European Parliament and of the Council of 19 July 2002 on the application of international accounting standards," Official Journal of the European Communities, L 243, Brussels, 2002.

[40] Rulebook on the contents and manner of public companies' reporting and notification on possession of voting shares, Belgrade, 2012

[41] Saini, J. S. and Herrmann, D., "Cost of Equity Capital, Information Asymmetry, and Segment Disclosure," Forthcoming, Advances in Quantitative Analysis of Finance and Accounting, [Online] [Accessed July 12, 2013] http://dx.doi.org/10.2139/ssrn.1758934

[42] Sheu, H-J., Chung, H. and Liu, C-L., "Comprehensive Disclosure of Compensation and Firm Value: The Case of Policy Reforms in an Emerging Market," in Journal of Business Finance \& Accounting, vol. 37, Issue 9-10, 2010, pp. 1115-1144. http://dx.doi.org/10.1111/j.1468-5957.2010.02213.x

[43] Sheu, H-J., Liu, C-L. and Yang, F-J., "The Determinants of Voluntary Disclosure of Directors' Compensation: Empirical Evidence from an Emerging Market," in Proceedings of the Conference on Behavioral Finance and Emerging Markets, 2008

[44] Singhvi, S. S. and Harsha, B. D., "An Empirical Analysis of the Quality of Corporate Governance Disclosure," in The Accounting Review, Jan. 1971, pp. 129-138.

[45] Spasić, D. and Denčić-Mihajlov, K., "Transparency of Financial Reporting in Serbia - Regulatory Framework and Reporting Practices," in Procedia Economics and Finance "The Economies of Balkan and Easter European Countries in the Changed World (EBEEC 2013)," Elsevier, vol. 9, 2014, pp. 153-162.

[46] Spasić, D., "Transparency of Financial Information - the EU-Capital Market's Requirement,“ in Proceedings of the Conference: „The tasks of accounting, auditing and financial professionals following the signing of the Stabilisation and Association Agreement" Banja Vrućica, Bosnia and Hercegovina, 2008, pp. 369-387. (in Serbian)

[47] Street, D. and Gray, S., "Observance of International Accounting Standards: Factors Explaining Non-compliance," ACCA Research Report $\mathrm{n}^{\circ}$ 74, London Certified Accountants Educational Trust, 2001.

[48] Yip, P. P., Isa, M., Kester, G. W. and Lee, S. P., "Share price reaction to dividend announcements and the interaction with earnings announcements in the Malaysian stock market," in Asian Journal of Business and Accounting, vol. 3, no. 2, 2010, pp. 101-120. 
[49] “Zakon o privatizaciji” (2001-2010), Sl. glasnik RS, br. 38/2001, 18/2003, 45/2005, 123/2007, 123/2007 i 30/2010, Beograd

[50] "Zakon o računovodstvu” (2013), Sl. glasnik RS br. 62/2013, Beograd

[51] "Zakon o računovodstvu i reviziji" (2006), Sl. gl RS br. 99/2006, Beograd

[52] "Zakon o reviziji" (2013), Sl. glasnik RS br. 62/2013, Beograd

[53] „Zakon o tržištu kapitala“" (2011), Sl. glasnik RS br. 31/2011, Beograd

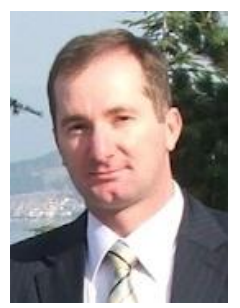

Dejan Spasić is currently an Aassociate Professor with the Faculty of Economics, the University of Niš, (Serbia). He received the Doctoral degree in Economics (specialization in Accounting) from the University of Belgrade (Serbia) in 2007. He teaches Financial Accounting, Consolidated Financial Statements, Special-purposes Balances. $\mathrm{He}$ is also a visiting professor at the University of Belgrade, Faculty of Economics. His research interests include international accounting, IFRS, financial analysis, auditing.

His academic work includes one textbook and more than 40 scientific papers published in domestic and international journals and participation in numerous domestic and international conferences.

$\mathrm{He}$ is a member of the European Accounting Association, Serbian Association of Accountants and Auditors, Serbian Society of Economics.

Address: Faculty of Economics Niš, Trg kralja Aleksandra Ujedinitelja 11, 18000 Niš, Serbia.

E-mail: dejan.spasic@eknfak.ni.ac.rs; spasicdejan@gmail.com

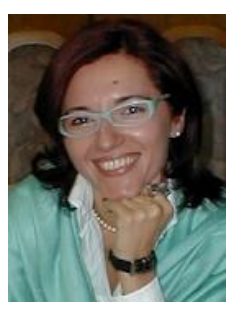

Ksenija Denčić-Mihajlov has been an Associate Professor with the Faculty Economics of the University of Niš, (Serbia) since 2010. She received the Doctoral degree in Economics from the University of Niš (Serbia). She teaches Corporate Finance and International Financial Management. Her research interests include corporate financing, capital budgeting, corporate restructurings, financial analysis.

Her academic work includes two textbooks and three monographs in Serbain language, articles published in international journals (such as the South-Eastern Journal of Economics, Ovidius University Annals: Economic Sciences Series, Accounting and Management Information Systems) and participation in numerous domestic and international conferences.

Address: Trg kralja Aleksandra Ujedinitelja 11, 18000 Niš, Serbia.

E-mail: ksenija@eknfak.ni.ac.rs 